University of Nebraska - Lincoln

DigitalCommons@University of Nebraska - Lincoln

$3-21-2007$

\title{
FOOD WEBS AND INTRAGUILD PREDATION: COMMUNITY INTERACTIONS OF A NATIVE MESOCARNIVORE
}

Craig. M. Thompson

Utah State University, cthompson@fs.fed.us

Eric M. Gese

USDA/APHIS/WS National Wildlife Research Center, eric.gese@usu.edu

Follow this and additional works at: https://digitalcommons.unl.edu/icwdm_usdanwrc

Part of the Environmental Sciences Commons

Thompson, Craig . M. and Gese, Eric M., "FOOD WEBS AND INTRAGUILD PREDATION: COMMUNITY INTERACTIONS OF A NATIVE MESOCARNIVORE" (2007). USDA National Wildlife Research Center - Staff Publications. 695.

https://digitalcommons.unl.edu/icwdm_usdanwrc/695

This Article is brought to you for free and open access by the U.S. Department of Agriculture: Animal and Plant Health Inspection Service at DigitalCommons@University of Nebraska - Lincoln. It has been accepted for inclusion in USDA National Wildlife Research Center - Staff Publications by an authorized administrator of DigitalCommons@University of Nebraska - Lincoln. 


\title{
FOOD WEBS AND INTRAGUILD PREDATION: COMMUNITY INTERACTIONS OF A NATIVE MESOCARNIVORE
}

\author{
Craig M. Thompson ${ }^{1,3}$ and Eric M. Gese ${ }^{2}$ \\ ${ }^{1}$ Department of Forest, Range, and Wildlife Sciences, Utah State University, Logan, Utah 84322-5210 USA \\ ${ }^{2}$ U.S. Department of Agriculture, Wildlife Services, National Wildlife Research Center, Department of Forest, Range, \\ and Wildlife Sciences, Utah State University, Logan, Utah 84322-5295 USA
}

\begin{abstract}
Trophic level interactions between predators create complex relationships such as intraguild predation. Theoretical research has predicted two possible paths to stability in intraguild systems: intermediate predators either outcompete higher-order predators for shared resources or select habitat based on security. The effects of intraguild predation on intermediate mammalian predators such as swift foxes (Vulpes velox) are not well understood. We examined the relationships between swift foxes and both their predators and prey, as well the effect of vegetation structure on swift fox-coyote (Canis latrans) interactions, between August 2001 and August 2004. In a natural experiment created by the Pinon Canyon Maneuver Site in southeastern Colorado, USA, we documented swift fox survival and density in a variety of landscapes and compared these parameters in relation to prey availability, coyote abundance, and vegetation structure. Swift fox density varied significantly between study sites, while survival did not. Coyote abundance was positively related to the basal prey species and vegetation structure, while swift fox density was negatively related to coyote abundance, basal prey species, and vegetation structure. Our results support the prediction that, under intraguild predation in terrestrial systems, top predator distribution matches resource availability (resource match), while intermediate predator distribution inversely matches predation risk (safety match). While predation by coyotes may be the specific cause of swift fox mortality in this system, the more general mechanism appears to be exposure to predation moderated by shrub density.
\end{abstract}

Key words: asymmetrical competition; Colorado, USA; food web; intraguild predation; safety match; Sobel test; swift fox; Vulpes velox.

\section{INTRODUCTION}

Over the past 65 years, the study of predator-prey relationships has steadily progressed from relatively simple interactions to complex, multi-trophic level relationships (Solomon 1949, Hairston et al. 1960, Paine 1966, Gratton and Denno 2003, Ives et al. 2005). Recently there has been "an explosion of interest in the complexities that arise from interactions within diverse predator-prey assemblages" (Ives et al. 2005). This has included the influence of habitat complexity (Finke and Denno 2004, Gruner 2004, Langellotto and Denno 2004), temporal or seasonal shifts in regulatory processes (Gratton and Denno 2003, Hampton 2004), direct vs. indirect effects (Fox and Olsen 2000, Navarrette et al. 2000), and guild-level effects (Sih et al. 1998, Finke and Denno 2004). A general synthesis has emerged that top-down and bottom-up forces act simultaneously (Hunter and Price 1992, Denno et al. 2002) and in concert with both biotic and abiotic forces (Power 1992, Meserve et al. 2003).

Manuscript received 21 April 2006; accepted 16 August 2006. Corresponding Editor: B. J. Danielson.

${ }^{3}$ Present address: Institute for Wildlife Studies, P.O. Box 584, Bass Lake, California 93604 USA.

E-mail: thompson@iws.org
Concurrent with this explosion, interest in intraguild predation (IGP), predators eating predators, has increased as well. Most natural food webs are not linear; predators must forage under the risk of predation by similar or higher-order predators (Polis et al. 1989, Rosenheim 2004). Trophic interactions between predators can lead to complex system dynamics (Polis et al. 1989, Navarrette et al. 2000, Heithaus 2001), and have forced ecologists to acknowledge less discrete trophic levels (Polis and Strong 1996, Sih et al. 1998). The vast majority of empirical evidence regarding the effect of intraguild predation on predator-prey dynamics comes from biological control studies and arthropod communities (Rosenheim et al. 1995, Snyder and Ives 2001). Such experiments have indicated that intraguild predation pressure is influenced by characteristics of the top predator (Wise 1993, Denno et al. 2002), behavior of the intermediate predator (Lucas et al. 1998), and habitat complexity (Finke and Denno 2002, Langellotto and Denno 2004). Local extinctions of intermediate predators due to intraguild predation pressure are often predicted (Holt and Polis 1997) and observed (Rosenheim 2001).

While there is ample evidence that intraguild predation dynamics exist in terrestrial mammalian systems (Ralls and White 1995, Creel and Creel 1996, Durant 
2000, Fedriani et al. 2000, Switalski 2003, Macdonald and Sillero-Zubiri 2004), there is almost no evidence regarding its effects on community dynamics or the influence of environmental heterogeneity. In particular, the effects on the intermediate predator, or intraguild prey, are largely unknown. While many of the predictions from arthropod studies are applicable to mammalian carnivore interactions, there are crucial differences. For example, in arthropod systems an increase in basal prey abundance often reduces the intensity of intraguild predation pressure (Rosenheim 2001, Denno et al. 2004). However, in mammalian systems intraguild predation is more characteristic of an extreme version of competition; intermediate predators are often killed but not consumed (Polis et al. 1989, Macdonald and Sillero-Zubiri 2004). Therefore the availability of basal prey may be expected to exert little influence. Mammalian intraguild predation is also often characterized by large differences in body size, creating strongly asymmetrical dynamics (Macdonald and Sillero-Zubiri 2004). These differences indicate that while arthropod research is useful in understanding mammalian predator interactions, these predictions must be viewed cautiously.

The potential for landscape or environmental factors influencing the relative strength of predator-prey interactions has also been widely discussed. The terms "mediating" or "moderating" are casually used and frequently interchanged in ecological research to indicate the effect of a third variable on a relationship. However, in biomedical research these terms not only have precise definitions, but rigorous statistical tests have been designed to evaluate the influence of a third variable on the relationship between dependent and independent variables. Here we introduce the use of the Sobel test to quantify the influence of landscape or environmental variables on species interactions (K. J. Preacher and G. J. Leonardelli, unpublished software). The Sobel test is relatively simple, using the coefficients and standard errors of linear regression to generate a Wald test statistic and an associated $P$ value. The $P$ value represents whether or not the inclusion of a second explanatory variable significantly altered the relationship between the dependent variable and the first explanatory variable (Fig. 1). For additional information on this or other tests associated with mediating variables, or examples from biomedical literature, see Sobel (1982) or Kenny et al. (1998). For precise definitions of moderating and mediating variables, see Baron and Kenny (1986).

In order to better understand the effect of intraguild predation on swift foxes (Vulpes velox), an intermediate mammalian predator of concern, illuminate the relative influence of top-down and bottom-up forces in terrestrial population dynamics, and to determine how these forces interact to determine swift fox distribution, we studied the ecology and demography of swift foxes in southeastern Colorado between August 2001 and August 2004. We monitored the influence of higher

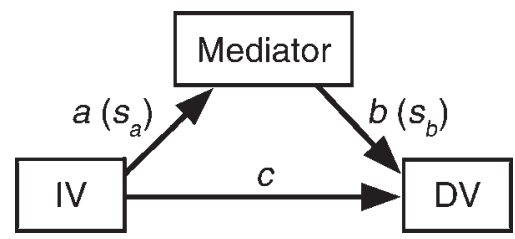

FIG. 1. Outline of the Sobel test from Preacher and Leonardelli (unpublished software) showing the influence of a third variable (mediator) on the relationship between an independent variable (IV) and dependent variable (DV). The regression coefficients are $a, b$, and $c ; s_{a}$ and $s_{b}$ indicate model standard error.

and lower trophic levels as well as vegetation structure on swift fox population dynamics. We used several multivariate analytical techniques, including the Sobel test, AIC (Akaike's information criterion), and hierarchical partitioning, to evaluate the relative strength of food web linkages. Our research centered on the Pinon Canyon Maneuver Site (PCMS), a U.S. Army owned mechanized infantry training facility in southeastern Colorado. Relatively recent changes in the local disturbance regimes, initiated following purchase of the PCMS by the U.S. Army in 1982, have created a natural experiment on the interactions of wildlife communities under different landscapes. While there was no true experimental control of treatments in our study, due to the temporal and spatial scale of terrestrial vertebrate research, observational studies following landscape-level changes are often the only available option. We therefore use the term "natural experiment" cautiously; our research was observational yet capitalized on a well-defined change in land-use practices and the resulting changes in landscape structure and food web dynamics.

\section{Methods}

Study area and system

We conducted research on and around the $1040-\mathrm{km}^{2}$ Pinon Canyon Maneuver Site (PCMS) located in northern Las Animas County, $\sim 50 \mathrm{~km}$ northeast of Trinidad, Colorado (Fig. 2). North of the PCMS, in Otero County, the study area extended into the United States Forest Service (USFS) Comanche National Grassland. The study area also extended southward onto private ranchlands. The study area was bordered by the Purgatoire River canyon complex to the east and U.S. Highway 350 to the west.

The region was classified as semiarid grassland steppe, with $\sim 60 \%$ of the PCMS categorized as shortgrass prairie dominated by blue grama (Bouteloua gracilis), western wheatgrass (Agropyron smithii), and galleta (Hilaria jamesii) (Shaw et al. 1989). Shrublands interspersed throughout the study area included four-winged saltbrush and greasewood (Sacrobatus vermiculatus), as well as prickly pear cactus (Opuntia phaeacantha), tree cholla (Cylindropuntia imbricata), and yucca (Yucca glauca). The remaining landscape was dominated by 


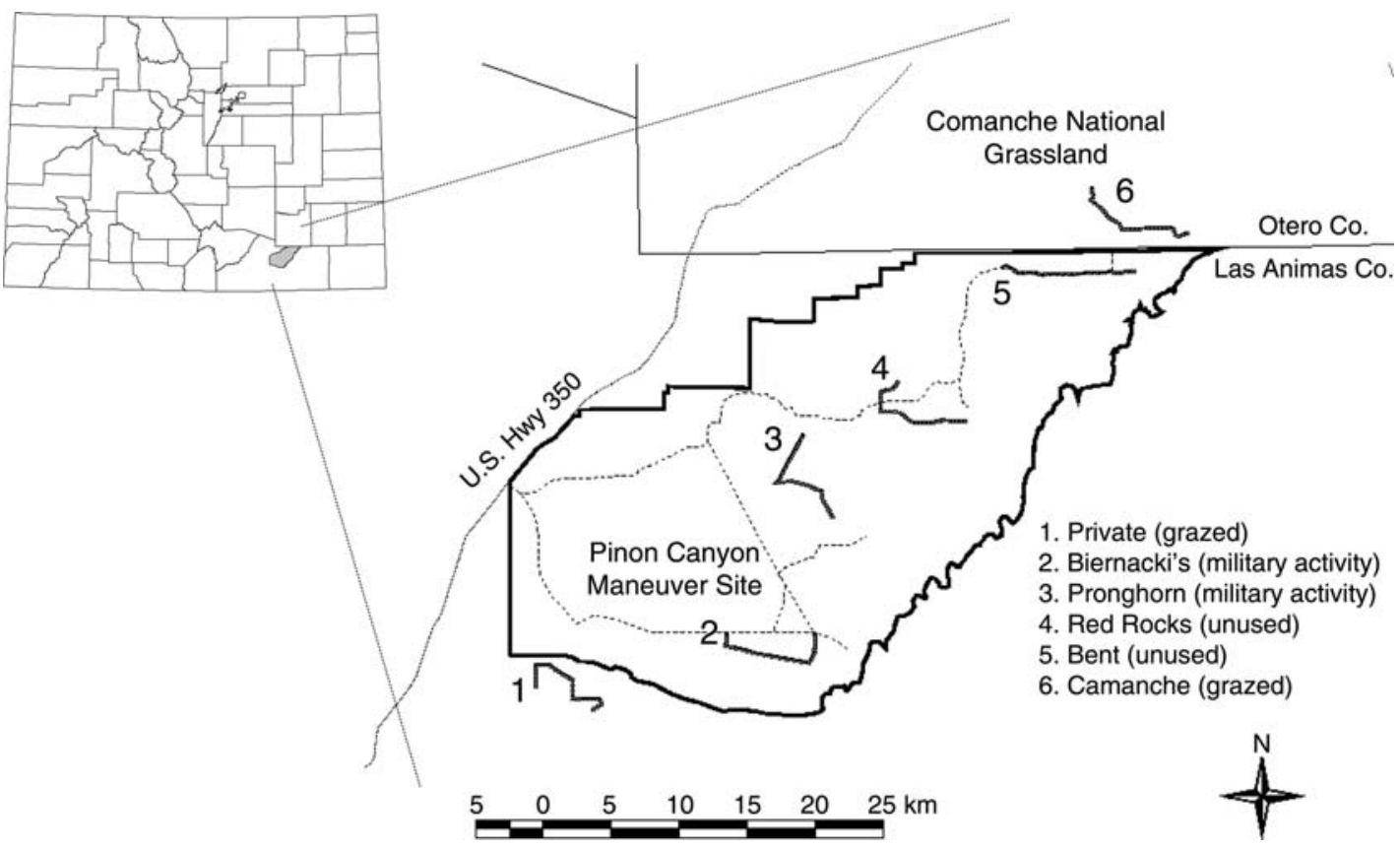

FIG. 2. Six study sites on and around the Pinon Canyon Maneuver Site in southeastern Colorado, USA. Locations of six transects are indicated, as well as the associated dominant land use for that site.

pinyon-juniper woodland (Pinus edulis, Juniperus monosperma). Elevation varied from 1310 to $1740 \mathrm{~m}$, average temperatures range from $1^{\circ} \mathrm{C}$ in January to $23^{\circ} \mathrm{C}$ in July, and precipitation averages $30 \mathrm{~cm}$ but fluctuates widely (Shaw and Diersing 1990). Monthly precipitation is highest in July with an average of $4.3 \mathrm{~cm}$ of rain, though the $35 \%$ of the annual precipitation that falls during the cool season (March-May) has a proportionally greater impact on productivity (Milchunas et al. 1999).

Prior to 1982, the region was used extensively for domestic livestock production and fires were infrequent due to the lack of available fuel. In 1982 the PCMS was purchased by the U.S. Army; grazing ceased and fire suppression efforts were initiated. Fire suppression was considered necessary because the release from grazing resulted in rapid biomass accumulation and an increase in fire frequency. In 1985 the U.S. Army commenced large-scale mechanized infantry training on the base. The shift from grazing to mechanized military training has had profound effects on the plant community, including reduced shrub density, increased bare ground, and decreased litter (Shaw and Diersing 1990, Milchunas et al. 1999). At the same time, portions of the PCMS unsuitable for training were left undisturbed and accumulated extensive basal coverage and litter. Examples of unsuitable areas included those containing archeological sites, sensitive plant species, or sections of the base separated from the main training area by enough topographic variation to preclude tank travel. Livestock production continues on the private and public land surrounding the PCMS. The abrupt shift in management practices and the well-documented effects on vegetation structure, in concert with the discrete boundaries of the base and the overall limited spatial scale, formed the basis for our natural experiment approach.

Southwestern grasslands are characterized by a nonlinear predator guild subject to intensive asymmetrical intraguild predation. Coyotes (Canis latrans) are the numerically dominant predator, though they compete with bobcats (Lynx rufus) and badgers (Taxidea taxus). Swift foxes are an intermediate predator, subject to predation by all three higher-order predators as well as golden eagles (Aquila chrysaetos). Despite the diversity of predators, coyote predation is the main cause of swift fox mortality (Sovada et al. 1998, Matlack et al. 2000, Schauster et al 2002a, Thompson 2006). The basal prey for these predators is characterized by a diverse small-mammal community (Ribble and Samson 1987); however the three most abundant species, Northern grasshopper mice (Onychomys leucogaster), Ord's kangaroo rat (Dipodomys ordii), and deer mice (Peromyscus maniculatus), dominate the community (Thompson 2006). Black-tailed jackrabbits (Lepus californicus) and desert cottontails (Sylvilagus audubonii) also form a large portion of the higher-order predators' diet, and are infrequently killed by swift foxes (Kitchen et al. 1999).

\section{Study design}

In order to deal with the range of spatial scales used by predators and prey, we developed a hierarchical study design. We identified six study sites in areas subjected to three land-use regimes: livestock grazing, 
mechanized military training, and unused (Fig. 2). Two study sites were located in each land-use regime. At each site, we established a $10-\mathrm{km}$ trapping transect. Within each site, we randomly placed $50 \times 70 \mathrm{~m}$ sampling grids within $1 \mathrm{~km}$ of the transect and at the rate of four grids per site per season over three years. We used a random number generator to create a distance along the transect, a direction (right or left), and a distance from the transect. This point became the northwest corner of the grid. These grids served as sampling units for both small-mammal trapping and vegetation structure surveys. We defined seasons as: winter, 15 December-14 April; summer, 15 April-14 August; and fall, 15 August-14 December, corresponding to swift fox breeding, pup-rearing, and dispersal behavior. New random locations were selected each season, resulting in 12 grids sampled per site per year.

While we assumed that differences in vegetation structure resulted primarily from differences in land use, each study site was considered an experimental unit due to the intrinsic small-scale variation between them. We attempted to minimize the effect of within-site heterogeneity through replication and the distribution of sites; however additional uncontrollable and confounding factors such as disturbance intensity, cattle stocking rates, and the degree of fire suppression precluded the use of a treatment-control design. Throughout the study, dispersing foxes regularly moved between sites indicating that all sites were potentially available habitat.

\section{Field methods}

We captured foxes using double-door box traps (Tomahawk Live Trap Company, Tomahawk, Wisconsin, USA) baited with raw chicken (Karki 2003). Traps were placed $500 \mathrm{~m}$ apart along each $10-\mathrm{km}$ trapping transect bisecting each study site, resulting in 21 trap locations per study site. Each trap was oriented and covered with brush to provide protection from exposure. Traps were set in the late afternoon, checked early the following morning, and left closed throughout the day. Each site was trapped for four consecutive nights three times per year. For recollaring or targeting animals, a trap-enclosure system was used at den sites (Kozlowski et al. 2003). Captured foxes were handled without anesthesia, weighed, sexed, and aged through tooth wear (adult, juvenile). Foxes were considered juvenile until the pup-rearing season following their birth (15 April). Foxes were ear-tagged and collared with 30-50 g radio transmitters (Advanced Telemetry Systems, Isanti, Minnesota, USA).

We located foxes a minimum of three times per week, twice during nighttime hours when animals were actively hunting and once during daylight hours to locate den sites. Mortality sensors within transmitters indicated when a collar had been stationary for 4-6 hours. When a mortality signal was detected, the transmitter was recovered immediately and the location was recorded.
Efforts to determine the cause of death included searching the area for tracks and other sign as well as through necropsy of any remains (Disney and Speigel 1992). We used Program MARK to calculate density and survival rates based on the known fate, logistic regression model (White and Burnham 1999). Known fate models based on telemetry data effectively accommodate staggered entry designs and use locations as recapture events to maximize estimate accuracy.

Coyote abundances were estimated using a scent station relative abundance index (Knowlton 1984). This has been shown to be a reliable, noninvasive method for estimating abundances of shy or nocturnal predators (Harrison et al. 2002). Scent stations consisted of a $1 \mathrm{~m}$ circle of sifted soil baited with a plaster disk soaked with fish oil. Stations were placed at 500-m intervals along each trapping transect, resulting in 21 stations per study site. Stations were baited and monitored for three consecutive nights, once each season. Tracks were identified and erased each morning; unknown tracks were digitally photographed for further identification. We estimated lagomorph abundances based on vehiclebased spotlight surveys conducted along each transect (Barnes and Tapper 1985, Ralls and Eberhardt 1997). Surveys were done over three consecutive nights once each season, and nightly totals were averaged for a seasonal count (Schauster et al. 2002b).

On each sampling grid, we evaluated vegetation structure using eight $50-\mathrm{m}$, north-south line transects following the short axis of the grid and spaced $10 \mathrm{~m}$ apart. Along each transect, we measured vegetation type and height at 1-m intervals (Dale 1999:41). Parameters estimated for each grid included live basal percent cover, percentage bare ground, percentage litter, mean grass height (centimeters), mean shrub height (centimeters), and shrub density (shrubs $/ 100 \mathrm{~m}^{2}$ ). We identified shrubs to species but not grasses or forbs.

Immediately following vegetation sampling, we placed 35 Sherman live traps with $10-\mathrm{m}$ spacing throughout the grid. Traps were baited with equine sweet feed, a mix of corn, oats, and molasses. Trapping grids were run for four consecutive nights, checked and closed each morning, and reset each afternoon. This method reduced our likelihood of capturing diurnal rodents such as ground squirrels, which due to high summer temperatures was required. Captured rodents were marked with Sharpie pens on the tail and abdomen allowing for identification of recaptures over the four-day trapping period. Relative abundance for each species was estimated based on the number of individuals captured. Available prey biomass for each grid was calculated as either total (number of individuals $\times$ average mass) or per capita (total biomass/total number of captures).

\section{Data analysis}

We used one-way ANOVA (SASv8, SAS Institute, Redlands, California, USA) to test whether transects differed in vegetation structure and predator communi- 
ty, followed by two-tailed $t$ tests for unequal variances to determine statistically similar groupings. Ratios of predator abundance were regressed against vegetative structure and prey base variables to assess the relative influence of lower trophic levels on the predator guild. In all analyses, we used annual estimates of survival and density for each site as dependent variables. We used the Sobel test (K. J. Preacher and G. J. Leonardelli, unpublished software) to evaluate the influence of vegetation structure on the relationship between coyote abundance and either swift fox density or survival.

We evaluated the relative strength of food web linkages using two methods: hierarchical partitioning (Chevan and Sutherland 1991) and information theoretic model averaging (Burnham and Anderson 2002). We used two methods due to the inherent weakness of AIC model averaging when dealing with a large number of candidate models, the tendency of different multivariate techniques to give slightly different answers, and our overall interest in interpreting food web patterns as opposed to the statistical significance of a particular relationship. We used hierarchical partitioning code for $\mathrm{R}$ written by Chris Walsh and available online at the Comprehensive R Archive Network (available online). ${ }^{4}$ This analysis calculates the goodness of fit for a single dependent variable to all possible combinations of independent variables in a multivariate data set, and partitions the explained variance. This analysis was conducted for each of the seven species (deer mice, northern grasshopper mice, Ord's kangaroo rat, desert cottontail, black-tailed jackrabbit, swift fox, coyote) independently using lower trophic level variables as independent, explanatory variables.

For each of the seven species, we then constructed a suite of candidate models consisting of all possible one, two, or three explanatory variables from lower trophic levels. We calculated AIC weights for each candidate model and summed the weights for all models in which a specific independent variable occurred as described by Burnham and Anderson (2002:167) in order to quantify the importance of individual model parameters. AIC weights depend upon the suite of models used; therefore values represented the relative importance of individual connections to a particular species but are not directly comparable between species. While using a large suite of candidate models is dangerous in AIC model selection, our intention was to explore the role of community web components using model averaging and not to create explanatory models. Under such an objective, an "all possible subsets" approach helps to explain individual variable contributions and avoid problems with multicollinearity (Graham 2003).

Due to the difficulties in combining data across spatial and temporal scales and the influence of spatial scale on food web topology (Navarrette et al. 2000, Thompson

${ }^{4}\langle$ http://www.r-project.org $\rangle$ and Townsend 2005), we used several data sets to illustrate food web dynamics. Interactions involving coyotes or swift foxes were evaluated at the spatial scale of study sites and temporal scale of the three-year study period due to their capacity for movement and relatively long generation time. We evaluated the relationship of lagomorphs to vegetative structure at the spatial scale of study sites but the temporal scale of individual years due to their rapid population dynamics. Finally, we evaluated the relationship between small mammals and vegetative structure at the scale of individual sampling grids. This hierarchy of scales allowed us to most appropriately represent interactions between different trophic levels. Interactions between species operating at different scales were scaled up to the coarser of the two scales.

\section{RESUlts \\ Site differences}

Between 20 November 2001 and 27 November 2004, 116 swift foxes were captured 238 times; 109 foxes were fitted with radio collars. Captures were not distributed equally among sites $\left(\chi^{2}=26.6, \mathrm{df}=5, P<0.001\right)$, with $86 \%$ of all captures occurring on the grazed or military sites and only $14 \%$ occurring on unused sites. Fifty-five confirmed deaths occurred (38 adult, 17 juvenile). Of these deaths, $22(40 \%)$ were coyote predation, three $(5 \%)$ badger predation, three $(5 \%)$ vehicle collision, two $(4 \%)$ golden eagle predation, one $(2 \%)$ bobcat predation, and 24 (44\%) unknown causes. Survival estimates did not differ significantly between seasons $(F=0.01, \mathrm{df}=2,27$, $P=0.99)$, by year $(F=0.98, \mathrm{df}=2,27, P=0.386)$, by age $(F=0.02, \mathrm{df}=2,27, P=0.891)$, or by site $(F=0.57, \mathrm{df}=$ $5,24, P=0.721$ ) (Table 1). Population density estimates of swift foxes differed by season and site (Table 1). Site was the most important factor for density estimates ( $F=$ 5.78, df $\left.=5,24, P=0.004, R^{2}=0.385\right)$. Season was a marginally significant variable influencing fox density $(F$ $=3.07, \mathrm{df}=2,27, P=0.057)$; however its inclusion raised the $R^{2}$ from 0.385 to 0.467 .

We evaluated vegetation structure on 185 sampling grids across the six study sites between December 2001 and August 2004. Basal percent cover did not vary significantly between sites, while percentage litter, mean grass height, and shrub density were significantly different between sites (Table 2). With respect to mean grass height, the Bent and Private sites were significantly different from each other as well as the other four sites. The remaining four sites did not differ. With respect to shrub density, three significantly different groups were indicated: Bent, Biernacki's, Private, and Red Rocks; Pronghorn and Private; and Comanche. Percentage litter also indicated three significantly distinct groups: Bent, Biernacki's, and Private; Biernacki's, Comanche, and Red Rocks; and Comanche, Pronghorn, and Red Rocks. These groupings did not correspond to land-use treatments, indicating heterogeneity between local landscapes and disturbance regimes. 
TABLE 1. Estimates (mean, with SE in parentheses) of population density and survival rates for adult swift foxes on six sites in southeastern Colorado, USA, 2001-2004.

\begin{tabular}{lccccc}
\hline \hline & & & \multicolumn{3}{c}{ Seasonal survival rates } \\
\cline { 4 - 6 } Site & Density $\left(\right.$ no. $\left./ \mathrm{km}^{2}\right)$ & Annual survival & Breeding & Pup rearing & Dispersal \\
\hline PRV & $0.18(0.10)$ & 0.54 & $0.81(0.09)$ & $0.83(0.08)$ & $0.81(0.09)$ \\
COM & $0.04(0.05)$ & 0.92 & $0.92(0.08)$ & $1.0(0.0)$ & $1.0(0.0)$ \\
BTS & $0.11(0.08)$ & 0.54 & $0.84(0.08)$ & $0.78(0.10)$ & $0.82(0.08)$ \\
PRN & $0.09(0.06)$ & 0.54 & $0.73(0.11)$ & $0.94(0.06)$ & $0.79(0.09)$ \\
RRK & $0.05(0.03)$ & 0.50 & $0.80(0.18)$ & $0.83(0.15)$ & $0.75(0.22)$ \\
BNT $\dagger$ & $0.03(0.05)$ & & & & \\
\hline
\end{tabular}

$†$ Throughout the study, only one animal remained and/or survived on the Bent site throughout a full season. As a result we were unable to estimate survival rates for that site.

\section{Predator distribution}

Swift fox densities on PCMS are negatively correlated with grass height, while coyote abundance is positively correlated with shrub density (Thompson 2006). Our simple linear regression results indicated that the ratio of swift fox density to coyote abundance was negatively related to all four vegetation structure variables measured (Fig. 3). However, three of the four relationships were statistically insignificant. Only shrub density was significantly negatively related to the predator ratio $\left(R^{2}=0.35, P=0.02\right)$.

\section{Prey distribution}

Lagomorph abundance was significantly positively correlated with shrub density $\left(R^{2}=0.33, P=0.006\right.$; Fig. 4). All other lagomorph/vegetation structure relationships were positive relationships; however, they were either statistically insignificant $(P>0.05)$ and/or had $R^{2}$ values $\leq 0.03$. These relationships did not vary seasonally, with the exception of black-tailed jackrabbits being observed more often in areas with taller grass during the winter season $\left(R^{2}=0.37, P=0.04\right)$.

Small-mammal communities were sampled on 185 grids throughout the study. Northern grasshopper mice, Ord's kangaroo rat, silky pocket mice (Perognathus flavus), western harvest mice (Reithrodontomys megalotis), white-footed mice (Peromyscus leucopus), southern plains woodrat (Neotoma micropus), 13-lined ground squirrels (Spermophilus tridecemlineatus), deer mice, and spotted ground squirrels (Spermophilus spilosoma) accounted for $>99 \%$ of all captures. Three species,
Northern grasshopper mice, deer mice, and Ord's kangaroo rat, accounted for $76 \%$ of all captures. Total small-mammal biomass was highest at moderate grass height (Fig. 5), decreasing in either direction. Smallmammal biomass peaked at either low or high shrub densities, primarily due to ground squirrel captures in areas of low shrub density and southern woodrat captures in areas of high shrub density. Total captures, another indicator of prey availability, was also highest at moderate grass height and peaked in areas of high shrub density (Fig. 5).

Hierarchical partitioning results indicated a variety of relationships between grassland prey species and vegetation structural characteristics (Fig. 6). Vegetation structure accounted for $14 \%$ of the variance in desert cottontail abundance, and $>90 \%$ of this resulted from a negative association with grass height and shrub density. Vegetation structure also accounted for $14 \%$ of the variance in black-tailed jackrabbit abundance, with $65 \%$ of this stemming from a positive association with shrub density. Relationships of the three most common smallmammal species with vegetation structure varied; northern grasshopper mice were associated with areas of increased grass height and basal percent cover while Ord's kangaroo rats were negatively associated with basal percent cover and shrub density. Deer mice favored areas of increased basal cover and shrub density but avoided areas with high percentage litter cover.

\section{Food web interactions}

Hierarchical partitioning results indicated a variety of relationships between predators and both lower trophic

TABLE 2. ANOVA results indicating differences in vegetation structural variables between study sites in southeastern Colorado, 2001-2004.

\begin{tabular}{|c|c|c|c|c|c|c|c|c|}
\hline \multirow[b]{2}{*}{ Site } & \multicolumn{2}{|c|}{ Basal percent cover } & \multicolumn{2}{|c|}{ Litter $(\%)$} & \multicolumn{2}{|c|}{ Grass height $(\mathrm{cm})$} & \multicolumn{2}{|c|}{ Shrub density (no. $/ 100 \mathrm{~m}^{2}$ ) } \\
\hline & Mean & Variance & Mean & Variance & Mean & Variance & Mean & Variance \\
\hline Bent & 0.44 & 0.05 & 0.17 & 0.01 & 12.79 & 23.54 & 1.15 & 0.90 \\
\hline Biernacki's & 0.40 & 0.03 & 0.18 & 0.02 & 9.53 & 25.99 & 0.71 & 0.98 \\
\hline Comanche & 0.45 & 0.04 & 0.25 & 0.02 & 10.60 & 9.80 & 2.71 & 4.07 \\
\hline Pronghorn & 0.35 & 0.02 & 0.26 & 0.02 & 8.92 & 18.24 & 0.26 & 0.08 \\
\hline Private & 0.38 & 0.04 & 0.18 & 0.01 & 6.69 & 15.58 & 0.92 & 4.98 \\
\hline Red Rocks & 0.44 & 0.03 & 0.23 & 0.02 & 9.36 & 8.91 & 0.68 & 0.72 \\
\hline
\end{tabular}

Note: For basal cover, $F_{5,179}=1.38, P=0.23$; for litter, $F_{5,179}=3.30, P=0.01$; for grass height, $F_{5,179}=6.84, P=<0.01$; and for shrub density, $F_{5,179}=12.01, P=<0.01$. 

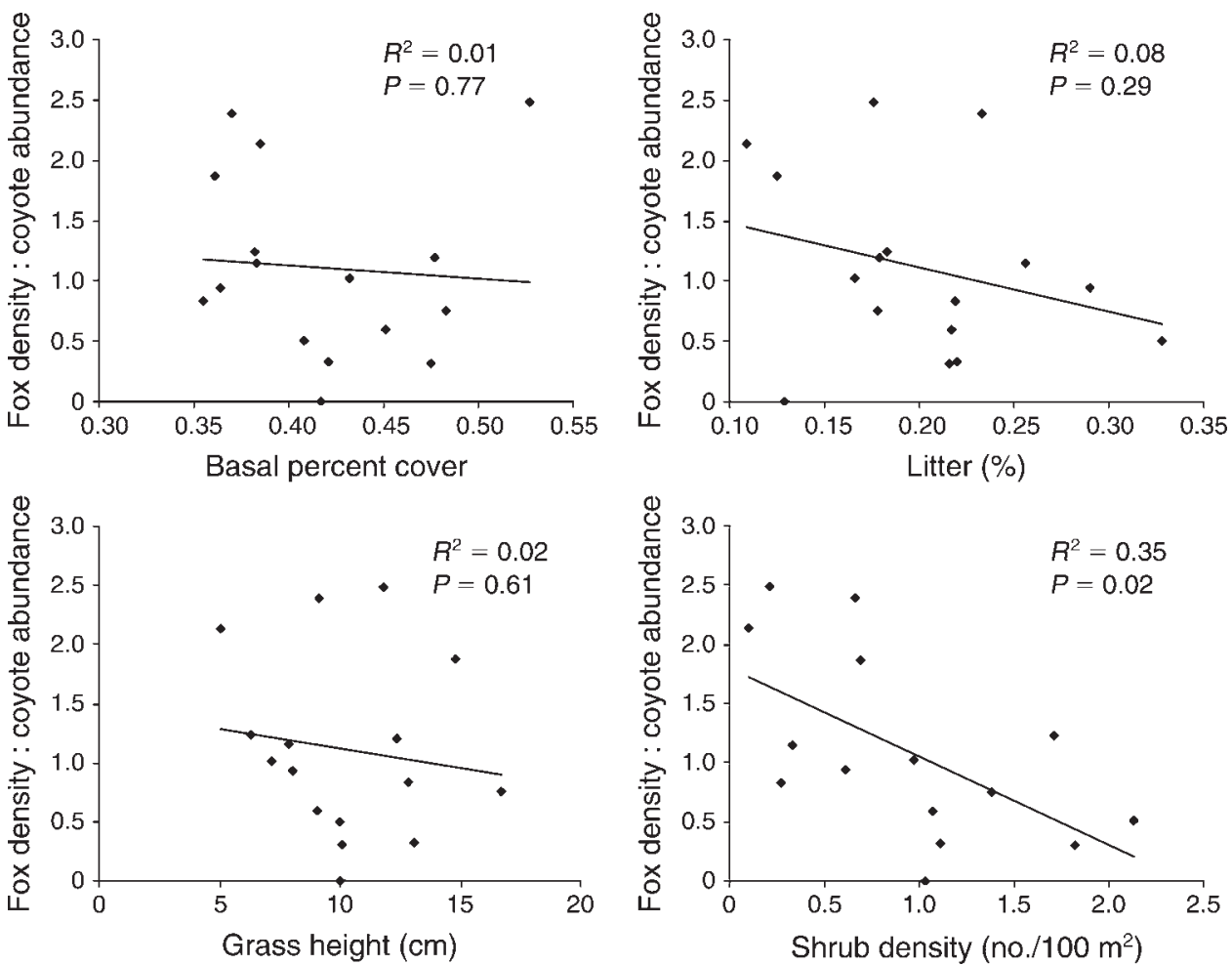

FIG. 3. Influence of vegetation structure variables on the ratio of swift fox density to coyote abundance in six study sites in southeastern Colorado, USA. Values represent seasonal averages for each study site between 2001 and 2004.
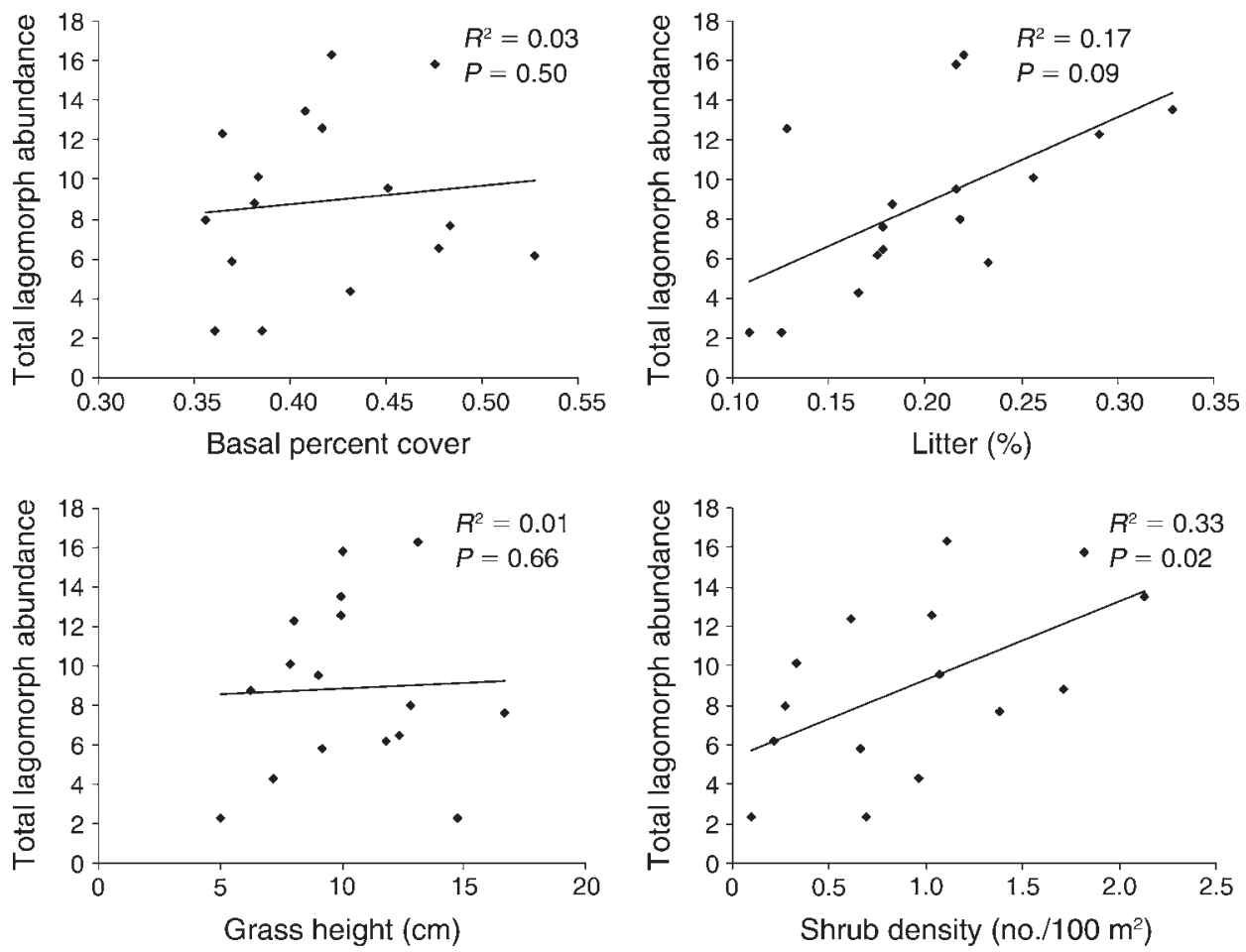

FIG. 4. Relationship between total lagomorph abundance (black-tailed jackrabbit and desert cottontail) and vegetation structure on the Pinon Canyon Maneuver Site, Colorado, USA. Values represent seasonal averages for each study site between 2001 and 2004. 
levels and vegetation structure (Fig. 7). Of the total variance in swift fox density, $44 \%$ was explained by the independent and joint contribution of prey species distribution, and another $34 \%$ was explained by vegetation structure variables. Of these, the dominant relationship was a negative association with black-tailed jackrabbit abundance, which accounted for $25 \%$ of the total explained variance. Forty-five percent of the variation in coyote abundance was explained by the same food web variables; of this, $68 \%$ was contributed by positive relationships with all four vegetation structure variables and another $17 \%$ was contributed by a positive relationship with black-tailed jackrabbit abundance. More importantly, coyotes and swift foxes showed a nearly perfect (eight of nine variables) pattern of opposite interactions; when coyotes were positively associated with a variable, swift foxes were negatively associated with the same variable and vice-versa (Fig. 7). Only percentage litter was positively associated with both predators.

This pattern of positive and negative interactions in food web dynamics was also indicated in the AIC model averaging results (Fig. 8). A negative relationship between one predator and a prey species was always balanced by a positive relationship between the other predator and the same prey species. Coyote abundance was positively related to three of five prey species and to all structural measures, though only the coyote: jackrabbit and coyote:shrub density relationships were statistically significant $\left(R^{2}=0.21\right.$ and $0.96, P=0.005$ and 0.0005 , respectively). In contrast, swift fox density was positively related to the remaining two prey species and negatively related to three of four structural measures, though again only one of each was statistically significant (swift fox : jackrabbit, $R^{2}=0.18, P=$ 0.01; swift fox : grass height, $R^{2}=0.76, P=0.02$ ). Only black-tailed jackrabbit abundance was significantly related to both predator populations, positively to coyotes and negatively to swift foxes.

The majority of interactions remained consistent, with respect to sign, significance, and magnitude, across seasons with two exceptions. First, the magnitude of the coyote: jackrabbit: swift fox relationship increased during winter. The $R^{2}$ value of the coyote/jackrabbit relationship increased from 0.21 to 0.54 , and from 0.18 to 0.61 for the jackrabbit/swift fox relationship. Second, predator-prey relationships weakened during fall months with $R^{2}$ values dropping an average of 0.08 . This dilution most likely represents a combination of enhanced movement during the dispersal season as well as the increased availability of arthropod prey during fall months (Kitchen et al. 1999).

Sobel test results indicated that only shrub density significantly altered the relationship between swift fox survival and coyote abundance. Fox survival was not significantly related to either coyote abundance or shrub density independently. However including shrub density in the fox survival: coyote abundance model raised the
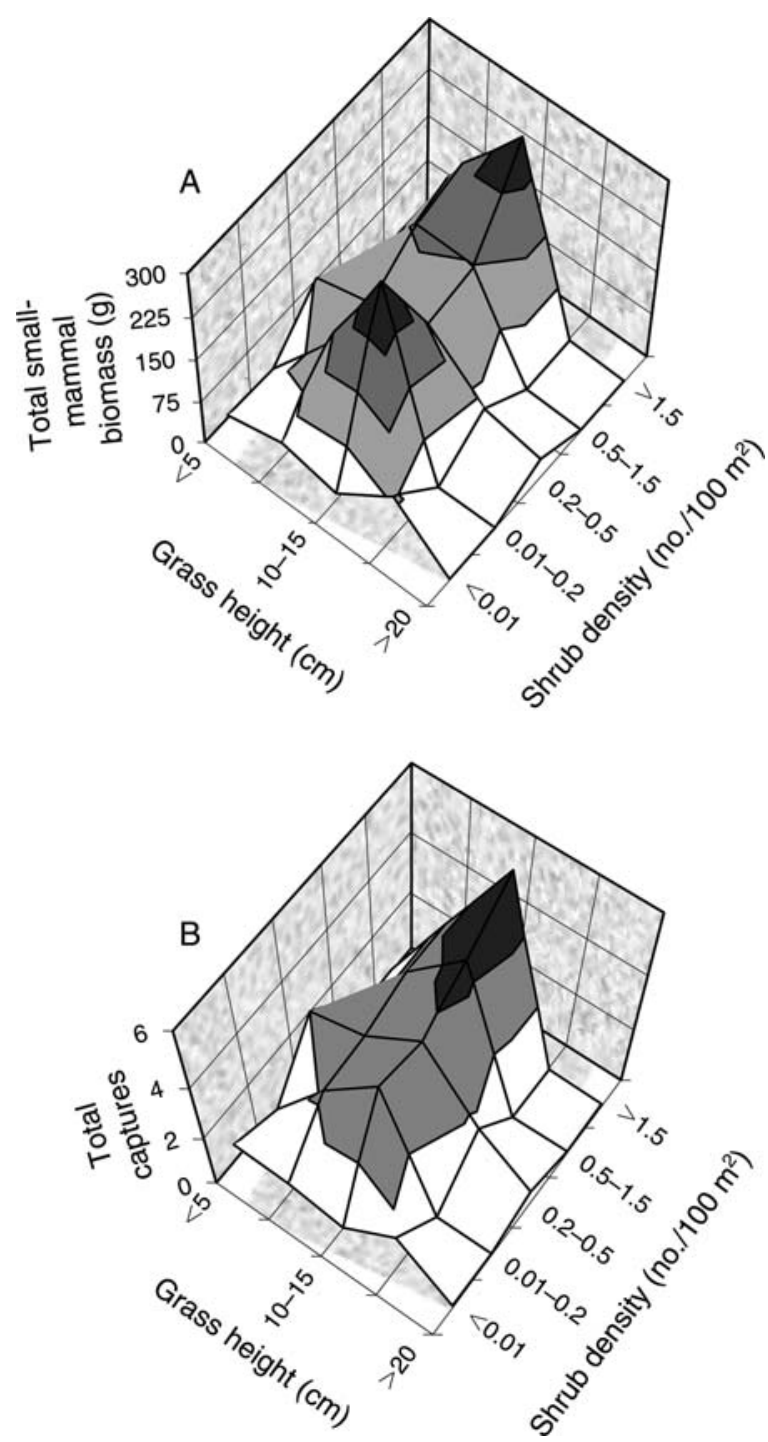

FIG. 5. Distribution of small-mammal (A) biomass and (B) captures in relation to vegetation structure in southeastern Colorado, 2001-2004.

$R^{2}$ value from 0.180 to 0.512 and lowered the $P$ value from 0.080 to 0.007 , a difference significant at the $P=$ 0.015 level (Table 3). Biologically, this indicates that in shrub-dominated habitat, swift fox survival is negatively related to coyote abundance, while in more open habitat it is not. No other vegetation structure variable significantly altered either the fox survival:coyote abundance or fox density: coyote abundance models.

\section{Discussion}

Traditional predator-prey models often predict what Sih (1998) termed the "leapfrog" effect, in which predators are most abundant in high quality prey habitat. This elevated predation risk moderates the advantage of habitat quality, and prey are more evenly distributed. This pattern has been observed in many 


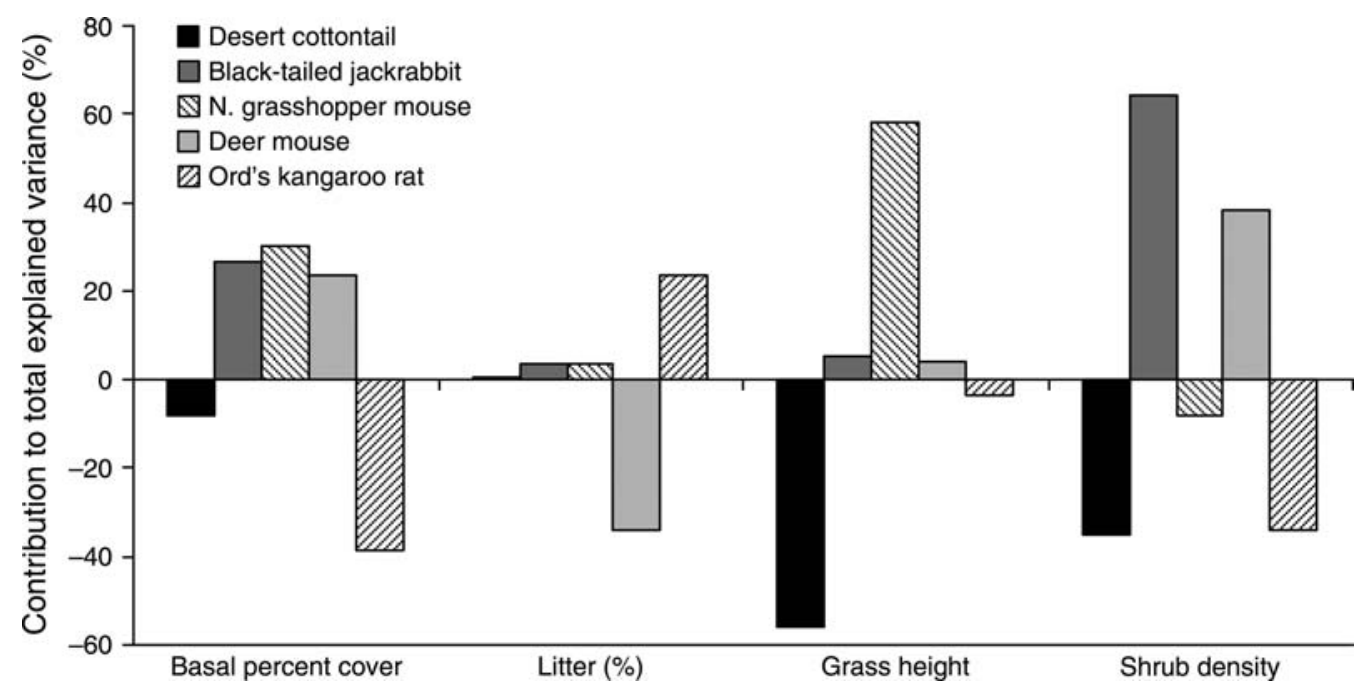

FIG. 6. Hierarchical partitioning results for prey species. Values indicate the percentage of the total explained variance for each species contributed by each explanatory variable. Negative values indicate a negative relationship.

linear trophic relationships (Kitchell et al. 1994). However, nonlinear relationships appear to be more common in natural systems (Rosenheim et al. 1995, Polis and Strong 1996), and behavior such as intraguild predation has the capacity to complicate predator-prey dynamics. In addition, while vegetation structure has been suggested as influential on arthropod predatorpredator interactions (Roda et al. 2000, Finke and Denno 2002), evidence from vertebrate systems is almost nonexistent.

Recent theoretical work has outlined two paths to system stability under intraguild predation. One is that intermediate predators must specialize and outcompete top predators for the shared basal prey in order to persist (Holt and Polis 1997). The second is that intermediate predators must disassociate from the more linear top predator-basal prey relationship and do what has been termed "safety-matching," selecting habitat based on security from predation rather than resource availability (Heithaus 2001, Rosenheim 2004).

In our study area, predator-prey dynamics appear to strongly conform to the second prediction, that top predators "resource match," intermediate predators "safety match," and shared basal prey are more evenly distributed. Both coyotes and swift foxes are opportunists, sharing prey species and capable of exploiting a range of habitats. While the majority of the predatorprey relationships were statistically insignificant, the repeated pattern of positive-negative relationships across multiple analytical techniques is strong indication of biological significance.

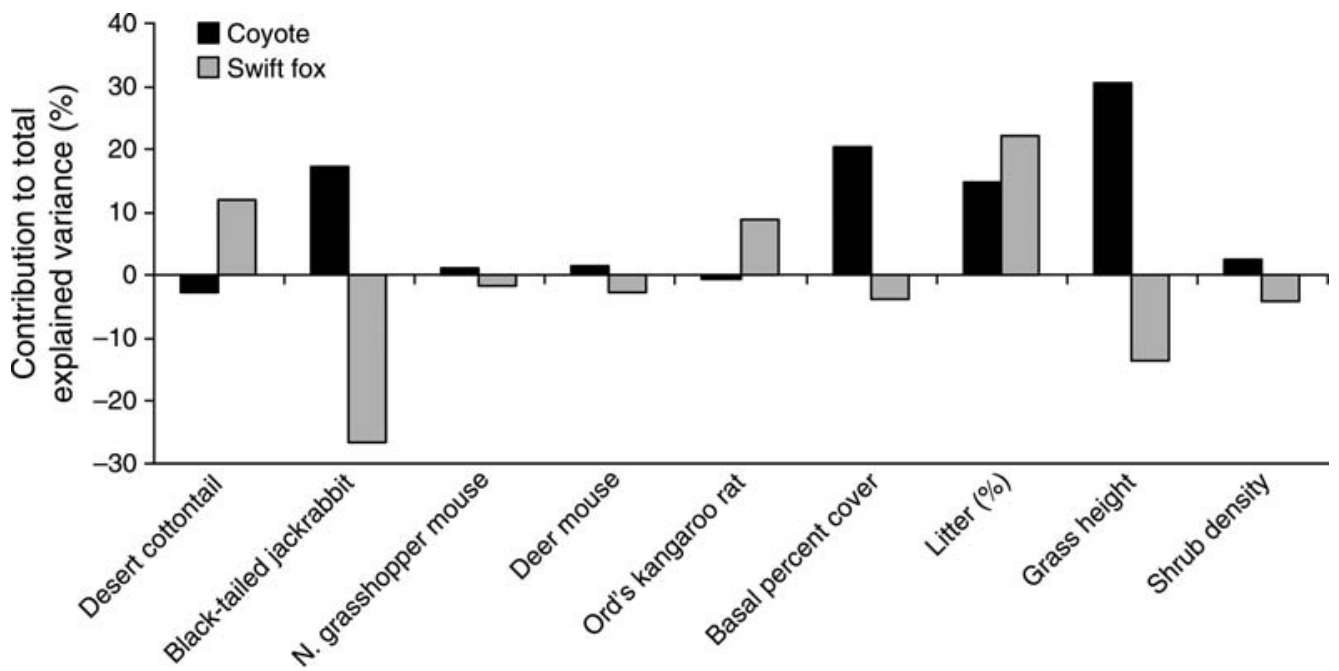

FIG. 7. Hierarchical partitioning results for two predator species. For each predator species, values indicate the percentage of the total explained variance in either abundance (coyote) or density (swift fox) contributed by each explanatory variable. Negative values indicate a negative relationship. 


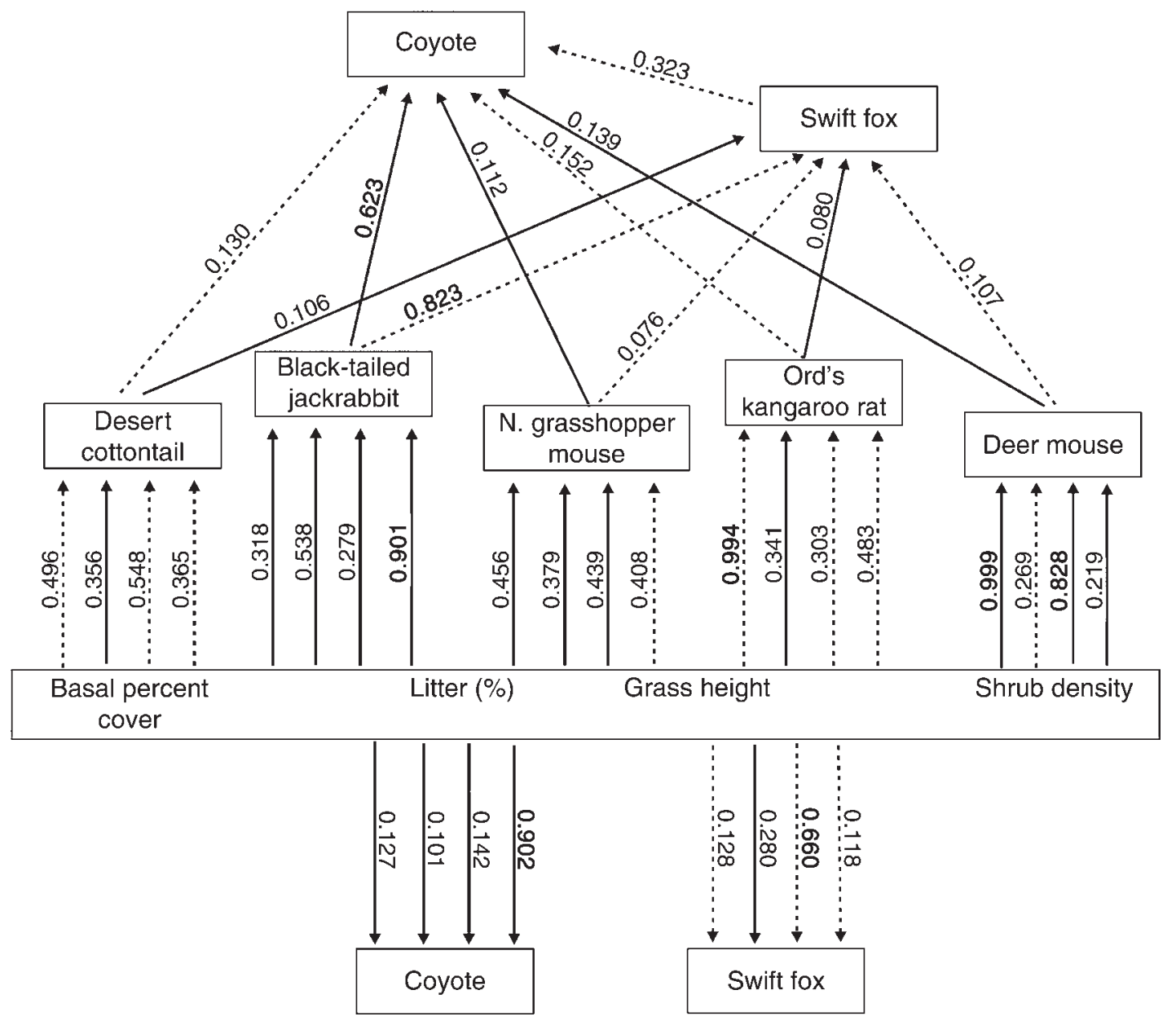

FIG. 8. Simplified food web diagram for southern Colorado showing the relationships between (A) all trophic levels and (B) vegetation structure and higher-order predators. Numbers indicate the summed AIC weights for all models in which that relationship occurred, and reflect the importance of an independent variable in the distribution of a particular species. Values $>0.60$ are indicated in boldface type. Solid arrows indicate positive relationships; dashed arrows indicate negative relationships. Arrows leaving the vegetation level indicate the four vegetation structure measurements in order. All values associated with arrows entering a particular species are directly comparable and reflect the relative importance of individual parameters. Values associated with arrows entering different species are not directly comparable due to the use of different candidate model suites for each species.

Both coyotes and swift foxes showed strong responses to vegetation structure. As predicted based on the leapfrog effect, coyotes were most abundant in areas of enhanced structural diversity where prey are typically more abundant. In contrast, swift fox density was negatively related to three of four structural measurements, significantly so with grass height. While they are capable of exploiting a wide variety of landscapes (Matlack et al. 2000), swift foxes are a fossorial species and depend on visually detecting predators and quickly escaping to a nearby den (FaunaWest, unpublished report). Landscapes where increased vegetation structure restricts line-of-sight, in the presence of higher-order predators, are risky habitats that are avoided. This behavior is validated based on the results of the Sobel test: shrub density significantly influenced the relationship between swift fox survival and coyote abundance. The idea that plant resources or habitat complexity moderates the strength of predator-predator and predator-prey interactions under intraguild predation has been well established in arthropod (Gratton and Denno 2003, Langellotto and Denno 2004) and aquatic (Hampton 2004) systems, but not in terrestrial vertebrate systems.

Our work suggests that changes in the disturbance regime have the capacity to exclude swift foxes from potential habitat due to subsequent changes in the vegetation structure. On the PCMS, the change in land use resulted in two interacting landscape trajectories; an increase in basal cover and grass height following the release from grazing and a reduction in basal cover, shrub height, and shrub density associated with military training (Shaw and Diersing 1990, Milchunas et al. 1999). The trajectory of landscape change appears to regulate the exposure of swift foxes to coyote predation more strongly than coyote abundance. Therefore while 
TABLE 3. Linear regression and Sobel test results outlining the influence of coyote abundance and/or vegetation structure on swift fox density and survival in southeastern Colorado, 2001-2004.

\begin{tabular}{|c|c|c|c|}
\hline Model & $R^{2}$ & Regression $P$ & Sobel test $P_{\dagger}^{\dagger}$ \\
\hline Fox density $=$ coyote abundance & 0.020 & 0.575 & \\
\hline Fox density $=$ shrub density & 0.030 & 0.508 & \\
\hline Fox density $=$ grass height & 0.354 & 0.009 & \\
\hline Fox density = basal percent cover & 0.179 & 0.080 & \\
\hline Coyote abundance $=$ shrub density & 0.581 & 0.0004 & \\
\hline Coyote abundance $=$ grass height & 0.0004 & 0.934 & \\
\hline Coyote abundance $=$ basal percent cover & 0.643 & 0.310 & \\
\hline Fox density $=$ coyote abundance + shrub density & 0.038 & 0.803 & 0.745 \\
\hline Fox density $=$ coyote abundance + grass height & 0.371 & 0.031 & 0.933 \\
\hline Fox density $=$ coyote abundance + basal percent cover & 0.180 & 0.225 & 0.371 \\
\hline Fox survival $=$ coyote abundance & 0.180 & 0.080 & \\
\hline Fox survival $=$ shrub density & 0.012 & 0.679 & \\
\hline Fox survival $=$ grass height & 0.037 & 0.440 & \\
\hline Fox survival $=$ basal percent cover & 0.001 & 0.905 & \\
\hline Fox survival $=$ coyote abundance + shrub density & 0.512 & 0.007 & 0.015 \\
\hline Fox survival $=$ coyote abundance + grass height & 0.226 & 0.146 & 0.934 \\
\hline Fox survival $=$ coyote abundance + basal percent cover & 0.199 & 0.188 & 0.597 \\
\hline
\end{tabular}

Note: $N=18$ : fall, winter, and summer averages across six study sites over three years.

$\dagger$ Sobel tests are used to evaluate the relative change in regression coefficients and standard errors due to the inclusion of a third variable in the model. A value of $P<0.05$ indicates that the inclusion of the third variable significantly altered the relationship between the dependent and independent variables.

the most visible source of swift fox mortality is coyote predation, the underlying cause is exposure to predation risk due to changes in landscape structure. This differentiation between direct sources of mortality and underlying causes may help explain the variation in published studies regarding the effect of coyote removal on swift fox population density (Kamler et al. 2003, Karki 2003).

Mammalian carnivores are relatively rare, wide ranging, and secretive, making empirical research on community interactions difficult (Fedriani et al. 2000, Switalski 2003). In particular, intraguild predation in mammalian carnivores, where the temporal and spatial scale of two or more such species must be considered, poses a significant challenge to wildlife ecologists (Creel and Creel 1996, Fedriani et al. 2000). As a result, while there is rapidly accumulating evidence that intraguild predation exists and plays an important role in shaping terrestrial predator guilds (see Macdonald and SilleroZubiri 2004 for a review) most evidence stops at documenting the interaction. There is currently very little information on the behavioral implications for either top or intermediate predators or the role of moderating factors such as landscape structure or habitat complexity.

Intraguild predation is a powerful evolutionary force capable of influencing species abundance, distribution, and behavior (Polis et al. 1989, Navarrette et al. 2000). In systems where the intraguild predation pressure is strongly asymmetrical, selection can be expected to favor behavioral responses by intermediate predators that reduce the probability of an interaction with a higher-order predator (Polis and McCormick 1987, Gerber and Echternacht 2000). Such behavioral changes have been documented for scorpions (Polis and Mc-
Cormick 1987), spiders (Wilder and Rypstra 2004), and lizards (Losos and Spiller 1999). Similar responses have been suggested in red fox (Vulpes vulpes)/coyote (Voigt and Earle 1983), coyote/wolf (Canis lupus; Switalski 2003), cheetah (Acinonyx jubatus)/lion (Panthera leo; Durant 2000) interactions; however the behavioral response of the intermediate predator and the mechanism of avoidance were not directly addressed. To our knowledge, only one study concerning intraguild predation between mammalian carnivores has specifically addressed the behavioral response of the intraguild prey. The density of African wild dogs (Lyacon pictus) is lowest where their primary prey, impala (Aepyceros melampus) and kudu (Tragelaphus strepsiceros), is most abundant (Mills and Gorman 1997). The authors concluded that wild dogs avoided prey-rich areas in order to avoid lions, the primary source of wild dog mortality, a behavior identical to that displayed by swift foxes in our study. In a more recent experimental study, Morris (2005) found that red-backed voles (Clethrionomys gapperi) altered their habitat selection to avoid food supplements, a paradox explained only when black bear (Ursus americanus) predation is taken into account.

While this was an observational study, the spatial and temporal scale of terrestrial carnivore behavior precludes most experimental approaches. The abrupt change in land management practices and the resulting shift in vegetation structure over the last 20 years, as well as the discrete boundaries maintained by the U.S. Army at the PCMS, created a heterogeneous system at a spatial scale appropriate for terrestrial carnivore research. While the intraguild predation of coyotes on swift foxes has been well documented, the subsequent effect on fox populations and behavior has not been addressed (Moehrenschlager et al. 2004). In this system, 
coyotes and swift foxes appeared to follow the predictions of resource and safety-matching outlined by Heithaus (2001) and Rosenheim (2004). Mesocarnivores, subject to a variety of selective forces, are often species of concern, and the mechanism by which they avoid higher-order predation is of direct management concern. Our results support Hunter and Price's (1992) contention that top-down (predation) and bottom-up (vegetation structure) act simultaneously and interact to control population densities (Leibold 1989), and suggest that vegetation structure plays a crucial role in moderating intraguild predation pressure on intermediate predators in terrestrial systems.

\section{ACKNOWLEDGMENTS}

Funding and assistance were provided by the U.S. Army, Directorate of Environmental Compliance and Management (DECAM), Fort Carson, Colorado, and the U.S. Fish and Wildlife Service, Colorado Assistance Office, Denver, Colorado. Additional support was provided by the U.S. Department of Agriculture, National Wildlife Research Center (NWRC) at Utah State University. Specific thanks go to T. Warren, G. Belew, R. Bunn, and R. Hill at DECAM and B. Rosenlund, D. Sharps, and M. Klavetter at the USFWS. Field assistance was provided by E. Joyce, J. White, E. Cleere, M. Watkins, D. Degeranno, A. Larkins, C. Roemer, D. Fletcher, W. Ulrey, S. Schopman, C. Gazal, A. Knipps, J. Garner, and C. Briggs. Drafts of this manuscript were reviewed by $\mathrm{M}$. Conner, $\mathrm{M}$. Ernst, J. MacMahon, F. Provenza, and two anonymous reviewers. Research protocols were approved by the Institutional Animal Care and Use Committees at the NWRC and Utah State University.

\section{Literature Cited}

Barnes, R. F. W., and S. C. Tapper. 1985. A method for counting hares by spotlight. Journal of Zoology 206:273-276.

Baron, R. M., and D. A. Kenny. 1986. The moderatormediator variable distinction in social psychological research: conceptual, strategic and statistical considerations. Journal of Personality and Social Psychology 51:1173-1182.

Burnham, K. P., and D. R. Anderson. 2002. Model selection and multimodel inference. Springer-Verlag, New York, New York, USA.

Chevan, A., and M. Sutherland. 1991. Hierarchical partitioning. American Statistician 45:90-96.

Creel, S. M, and N. Creel. 1996. Limitation of African wild dogs by competition with larger carnivores. Conservation Biology 10:526-538.

Dale, M. R. 1999. Spatial pattern analysis in plant ecology. Cambridge University Press, Cambridge, UK.

Denno, R. F., C. Gratton, G. A. Langellotto, D. L. Finke, A. F. Huberty, and M. A. Peterson. 2002. Bottom-up forces mediate natural enemy impact in a phytophagous insect community. Ecology 83:1443-1458.

Denno, R. F., M. S. Mitter, G. A. Langellotto, C. Gratton, and D. L. Finke. 2004. Interactions between a hunting spider and a web-builder: consequences of intraguild predation and cannibalism for prey suppression. Ecological Entomology 29: 566-577.

Disney, M., and L. K. Speigel. 1992. Sources and rates of San Joaquin kit fox mortality in western Kern County, California. Transactions of the Western Section of the Wildlife Society $28: 73-82$.

Durant, S. M. 2000. Living with the enemy: avoidance of hyenas and lions by cheetahs in the Serengeti. Behavioral Ecology 11:624-632.
Fedriani, J. M., T. K. Fuller, R. M. Sauvajot, and E. C. York. 2000. Competition and intraguild predation among three sympatric carnivores. Oecologia 125:258-270.

Finke, D. L., and R. F. Denno. 2002. Intraguild predation diminished in complex-structured vegetation: implications for prey suppression. Ecology 83:643-652.

Finke, D. L., and R. F. Denno. 2004. Predator diversity dampens trophic cascades. Nature 429:407-410.

Fox, J. W., and E. Olsen. 2000. Food web structure and the strength of transient indirect effects. Oikos 90:219-226.

Gerber, G. P., and A. C. Echternacht. 2000. Evidence for asymmetrical intraguild predation between native and introduced Anolis lizards. Oecologia 124:599-607.

Graham, M. H. 2003. Confronting multicollinearity in ecological multiple regression. Ecology 84:2809-2815.

Gratton, C., and R. F. Denno. 2003. Seasonal shift from bottom-up to top-down impact in phytophagous insect populations. Oecologia 134:487-495.

Gruner, D. S. 2004. Attenuation of top-down and bottom-up forces in a complex terrestrial community. Ecology 85:3010 3022.

Hairston, N. G., F. E. Smith, and L. B. Slobodkin. 1960. Community structure, population control, and competition. American Naturalist 94:421-425.

Hampton, S. E. 2004. Habitat overlap of enemies: temporal patterns and the role of spatial complexity. Oecologia 138: $475-484$.

Harrison, R. L., D. J. Barr, and J. W. Dragoo. 2002. A comparison of population survey techniques for swift fox (Vulpes velox) in New Mexico. American Midland Naturalist 148:320-337.

Heithaus, M. R. 2001. Habitat selection by predators and prey in communities with asymmetrical intraguild predation. Oikos 92:542-554.

Holt, R. D., and G. A. Polis. 1997. A theoretical framework for intraguild predation. American Naturalist 149:745-764.

Hunter, M. D., and P. W. Price. 1992. Playing chutes and ladders: heterogeneity and the relative roles of bottom-up and top-down forces in natural communities. Ecology 73 : $724-732$

Ives, A. R., B. J. Cardinale, and W. E. Snyder. 2005. A synthesis of subdisciplines: predator-prey interactions, and biodiversity and ecosystem functioning. Ecology Letters 8: 102-116.

Kamler, J. F., W. B. Ballard, R. L. Gilliland, P. R. Lemons, and K. Mote. 2003. Impacts of coyotes on swift foxes in northwestern Texas. Journal of Wildlife Management 67: 317-323.

Karki, S. M. 2003. Effects of coyote removal on swift fox (Vulpes velox) population ecology in southeastern Colorado. Thesis. Utah State University, Logan, Utah, USA.

Kenny, D. A., and D. A. Kashy. and N. Bolger. 1998. Data analysis in social psychology. Pages 233-265 in D. Gilbert, S. Fiske, and G. Lindzey, editors. The handbook of social psychology. McGraw-Hill, Boston, Massachusetts, USA.

Kitchell, J. F., L. A. Eby, X. He, D. E. Schindler, and R. A. Wright. 1994. Predator-prey dynamics in an ecosystem context. Journal of Fish Biology 45:209-226.

Kitchen, A. M., E. M. Gese, and E. R. Schauster. 1999. Resource partitioning between coyotes and swift foxes: space, time, and diet. Canadian Journal of Zoology 77:1645-1656.

Knowlton, F. F. 1984. Feasibility of assessing coyote abundance on small areas. Final Report, Work Unit 909: 01, Denver Wildlife Research Center, Denver, Colorado, USA.

Kozlowski, A. J., T. J. Bennet, E. M. Gese, and W. M. Arjo. 2003. Live capture of denning mammals using an improved box-trap enclosure: kit foxes as a test case. Wildlife Society Bulletin 31:630-633.

Langellotto, G. A., and R. F. Denno. 2004. Responses of invertebrate natural enemies to complex-structured habitats: a meta-analytical synthesis. Oecologia 139:1-10. 
Liebold, M. A. 1989. Resource edibility and the effects of predators and productivity on the outcome of trophic interactions. American Naturalist 134:922-949.

Losos, J. B., and D. A. Spiller. 1999. Differential success and asymmetrical interactions between two lizard species. Ecology 80:252-258.

Lucas, E., D. Coderre, and J. Brodeur. 1998. Intraguild predation among aphid predators: characterization and influence of extraguild prey. Ecology 79:1084-1092.

Macdonald, D. W., and C. Sillero-Zubiri. 2004. Biology and conservation of wild canids. Oxford University Press, Oxford, UK.

Matlack, R. S., P. S. Gipson, and D. W. Kaufman. 2000. The swift fox in rangeland and cropland in western Kansas: relative abundance, mortality, and body size. Southwestern Naturalist 45:221-225.

Meserve, P. L., D. A. Kelt, W. B. Milstead, and J. R. Gutierrez. 2003. Thirteen years of shifting top-down and bottom-up control. BioScience 53:633-646.

Milchunas, D. G., K. A. Schulz, and R. B. Shaw. 1999. Plant community responses to disturbance by mechanized military maneuvers. Journal of Environmental Quality 28:1533-1547.

Mills, M. G. L., and M. L. Gorman. 1997. Factors affecting the density and distribution of wild dogs in the Kruger National Park. Conservation Biology 11:1397-1406.

Moehrenschlager, A., B. L. Cypher, K. Ralls, R. List, and M. A. Sovada. 2004. Swift and kit foxes. Pages 185-198 in D. W. Macdonald and C. Sillero-Zubiri, editors. Biology and conservation of wild canids. Oxford University Press, Oxford, UK.

Morris, D. W. 2005. Paradoxical avoidance of enriched habitats: Have we failed to appreciate omnivores? Ecology $86: 2568-2577$.

Navarrette, S. A., B. A. Menge, and B. A. Daley. 2000. Species interactions in intertidal food webs: prey or predation regulation of intermediate predators? Ecology 81:2264-2277.

Paine, R. T. 1966. Food web complexity and species diversity. American Naturalist 100:65-75.

Polis, G. A., and S. J. McCormick. 1987. Intraguild predation and competition among desert scorpions. Ecology 68:332343.

Polis, G. A., C. A. Myers, and R. D. Holt. 1989. The ecology and evolution of intraguild predation: potential competitors that eat each other. Annual Review of Ecology and Systematics 20:297-330.

Polis, G. A., and D. R. Strong. 1996. Food web complexity and community dynamics. American Naturalist 147:813-846.

Power, M. E. 1992. Top-down and bottom-up forces in food webs: do plants have primacy? Ecology 73:733-746.

Ralls, K., and L. L. Eberhardt. 1997. Assessment of the abundance of San Joaquin kit foxes by spotlight surveys. Journal of Mammalogy 78:65-73.

Ralls, K., and P. White. 1995. Predation on San Joaquin kit foxes by larger canids. Journal of Mammalogy 76:723-729.

Ribble, D., and F. B. Samson. 1987. Microhabitat associations of small mammals in southeastern Colorado, with special emphasis on Peromyscus (Rodentia). Southwestern Naturalist 32:291-303.

Roda, A., J. Nyrop, M. Dicke, and G. English-Loeb. 2000. Trichomes and spider-mite webbing protect predatory mite eggs from intraguild predation. Oecologia 125:428-435.

Rosenheim, J. A. 2001. Source-sink dynamics for a generalist insect predator in habitats with strong higher-order predation. Ecological Monographs 71:93-116.
Rosenheim, J. A. 2004. Top predators constrain the habitat selection games played by intermediate predators and their prey. Israel Journal of Zoology 50:129-138.

Rosenheim, J. A., H. K. Kaya, L. E. Ehler, J. J. Marois, and B. A. Jaffee. 1995. Intraguild predation among biologicalcontrol agents: theory and evidence. Biological Control 5: 303-335.

Schauster, E. R., E. M. Gese, and A. M. Kitchen. $2002 a$. Population ecology of swift foxes (Vulpes velox) in southeastern Colorado. Canadian Journal of Zoology 80:307-319.

Schauster, E. R., E. M. Gese, and A. M. Kitchen. 2002b. An evaluation of survey methods for monitoring swift fox abundance. Wildlife Society Bulletin 20:464-477.

Shaw, R. B., S. L. Anderson, K. A. Schulz, and V. E. Diersing. 1989. Plant communities, ecological checklist, and species list for the U.S. Army Pinon Canyon Maneuver Site, Colorado. Colorado State University Science Series 37. Fort Collins, Colorado, USA.

Shaw, R. B., and V. E. Diersing. 1990. Tracked vehicle impacts on vegetation at the Pinon Canyon Maneuver Site, Colorado. Journal of Environmental Quality 19:234-243.

Sih, A. 1998. Game theory and predator-prey response races. Pages 221-238 in L. A. Dugatin and H. K. Reeve, editors. Game theory and animal behavior. Oxford University Press, New York, New York, USA.

Sih, A., G. Englund, and D. Wooster. 1998. Emergent impacts of multiple predators on prey. Trends in Ecology and Evolution 13:350-355.

Snyder, W. E., and A. R. Ives. 2001. Generalist predators disrupt biological control by a specialist parasitoid. Ecology 82:705-716.

Sobel, M. E. 1982. Asymptotic confidence intervals for indirect effects in structural equation models. Pages $290-312$ in S. Leinhardt, editor. Sociological methodology 1982. American Sociological Association, Washington, D.C., USA.

Solomon, M. E. 1949. The natural control of animal populations. Journal of Animal Ecology 18:1-35.

Sovada, M. A., C. C. Roy, J. B. Bright, and J. R. Gillis. 1998. Causes and rates of mortality in swift foxes in western Kansas. Journal of Wildlife Management 62:1300-1306.

Switalski, T. A. 2003. Coyote foraging ecology and vigilance in response to gray wolf reintroduction in Yellowstone National Park. Canadian Journal of Zoology 81:985-993.

Thompson, C. M. 2006. Landscape-level influences on swift fox (Vulpes velox) demographics in southeastern Colorado. Dissertation. Utah State University, Logan, Utah, USA.

Thompson, R. M., and C. R. Townsend. 2005. Food-web topology varies with spatial scale in a patchy environment. Ecology 86:1916-1925.

Voigt, D. R., and B. D. Earle. 1983. Avoidance of coyotes by red fox families. Journal of Wildlife Management 47:852857.

White, G. C., and K. P. Burnham. 1999. Program MARK: survival estimation from populations of marked animals. Bird Study 46(Supplement):120-138.

Wilder, S. M., and A. L. Rypstra. 2004. Chemical cues from an introduced predator (Mantodea, Mantidae) reduce the movement and foraging of a native wolf spider (Araneae, Lycosidae) in the laboratory. Environmental Entomology 33: 1032-1036.

Wise, D. H. 1993. Spiders in ecological webs. Cambridge University Press, Cambridge, UK. 